\title{
Improving Critical Thinking Skills in Teaching through Problem-Based Learning for Students: A Scoping Review
}

\author{
Azila Abdul Razak* ${ }^{(D)}$, Mohamad Rohieszan Ramdan ${ }^{(D)}$ and \\ Nurhanie Mahjom \\ Faculty of Management and Economics, \\ Universiti Pendidikan Sultan Idris, Tanjong Malim, Perak, Malaysia \\ Mohd Nazir Md. Zabit \\ Faculty of Human Development, \\ Universiti Pendidikan Sultan Idris, Tanjong Malim, Perak, Malaysia \\ Fidlizan Muhammad $D$ and Mohd Yahya Mohd Hussin \\ Faculty of Management and Economics, \\ Universiti Pendidikan Sultan Idris, Tanjong Malim, Perak, Malaysia \\ Nor Liza Abdullah \\ Faculty of Economics and Management, \\ Universiti Kebangsaan Malaysia, Bangi, Selangor, Malaysia
}

\begin{abstract}
Critical thinking is an important skill for graduates in 21st century teaching and learning. One of the modern educational pedagogies which can be utilized by educators to inculcate students' critical thinking skills and improve student learning effectively is the problem-based learning (PBL) approach. The Web of Science, Scopus, and ProQuest databases have been used to source published scientific literature on this topic and develop themes of critical thinking abilities in teaching through PBL for students. This study revealed four major themes and nine sub-themes with regards to critical thinking skills in teaching in relation to PBL. The major themes consisted of the learning environment, content, process, and human capital. The review revealed that most of the studies were conducted to understand critical thinking skills in problem-based learning. This study found that PBL was a major approach used in teaching students, as well as a wide range of other techniques that may develop diverse abilities, such as thinking critically and creatively, solving problems, collaborating, communicating
\end{abstract}

\footnotetext{
*Corresponding author: Azila Abdul Razak, azila@fpe.upsi.edu.my
} 
effectively, and global literacy. This paper also highlights the challenges in developing critical thinking among students and identifies topics for further research.

Keywords: educational pedagogies, critical thinking skills, problembased learning, scoping review, students

\section{Introduction}

Critical thinking is an important aspect of modern education that should be developed and empowered especially in the current fourth industrial revolution (4IR) (Wilson \& Narasuman, 2020; Boleng et al., 2017; Hidayati et al., 2020), where information is in abundance and changes are rapid and radical. Critical thinking skills are widely recognized as an essential element in the modern educational system and all educators need to implement effective teaching and learning approaches to help students develop and strengthen their thinking skills (Moust et al., 2019). To think critically, one requires a rational mind with good reasoning, as well as the ability to follow logical rules, and scientific reasoning as the best foundation for making decisions.

From Facione's perspective, one must employ core thinking skills to think critically, such as creating inferences, investigating assumptions, making deductions or reasoning, making interpretations, and making judgments (Hajhosseini et al., 2016). Critical thinking is also perceived as a cognitive skill associated with logical analysis and argument evaluations to determine logical acts (Alvarez-Huerta et al., 2022; Orakci, 2021; Papp et al., 2014; Stupnisky et al., 2008).

The development of critical thinking skills has been regarded as one of the most substantial objectives of education for over a century (Jatmiko et al., 2018; Suarniati et al., 2019). According to Hsu (2021), in general, there are three parts in critical thinking: knowledge (topic knowledge, technique knowledge, selfknowledge, and environment knowledge); dispositions (logical integrity, logical humanity, logical modesty, logical bravery, logical persistence, etc.); and skills or abilities. Numerous scholars suggest that critical thinking consists of interpreting, analyzing, synthesizing, concluding, evaluating information, explaining, and selfregulation (Wale \& Bishaw, 2020), which are achieved through observation, experience, reasoning, or communication (Piawa, 2010; Ulger, 2018). Critical thinking is also related to cognitive skills because it involves problem-solving activities; understanding interactions of factors that influence the outcomes; and calculating various possibilities and scenarios to make the right decision (Erikson \& Erikson, 2019). Additionally, critical thinking is also related to other abilities, such as scientific communication, students' self-confidence, and motivation ( $\mathrm{Hu}$ et al., 2016).

As stated by Saputro et al. (2020), PBL approaches should be used by educators to develop critical thinking abilities among students. Considering the definition of critical thinking, the objective of this scoping review is to analyze the published scientific literature related to critical thinking skills development among students using PBL. From this comprehensive review, a map of emerging patterns related 
to research in the topic of critical thinking skills development among students has been constructed.

\subsection{PBL and Critical Thinking Skills}

According to Scott (2017) and Hmelo-Silver (2004), PBL was derived from the experiential learning theory; a theory that can help bridge the gap between education and employment. This theory explains how students can develop analytical skills through problem-solving. In other words, educators will rejuvenate students' intelligence through the process of finding solutions to problems or scenarios which involve the interaction of multiple factors that need to be taken into account when making decisions. This idea is parallel to the concept of scaffolding based on the constructivism learning theory outlook (Dolmans, 2019; Hmelo-Silver, 2004). In relation to this, researchers believe that with the utilization of PBL-based modules, students can invigorate their thinking and problem-solving skills and improve their academic performance (Yew \& Goh, 2016). An empirical study regarding the effectiveness of PBL Newtonian laws topic by Loyens et al. (2015) revealed that students who were involved in PBL achieved higher academic performance than those from traditional learning groups. Furthermore, PBL is a multi-level learning approach that includes relevance and complexity while improving critical and analytical thinking, as well as providing opportunities for self-assessment and continual growth (Caspary \& Wickstrom, 2017).

In essence, the PBL process takes place in groups, and independent learning provides new information (Scott, 2017; Hmelo-Silver \& Barrows, 2008; O'Grady, 2012; Barrow et al., 2002). Problems are presented before applied learning takes place in problem-based learning. Students must formulate an understanding of the problem and perform investigations to come up with answers or solutions (Saputro et al., 2020). During the investigation, students need to relate the concepts learnt in the subject and apply their understanding of the concepts to solve the problem. According to Overton and Randles (2015), PBL is important because it allows students to think critically and solve unstructured real-world situations.

Previous empirical studies have focused more on the impact of critical thinking skills in a variety of subjects, such as geography (Amin et al., 2020), biology (Boleng et al., 2017), medical (Foo et al., 2021), sport, and exercise psychology (Heaviside et al., 2018), dental (Oderinu et al., 2020), engineering ethics (Hsu, 2021) and others. They also claimed that the PBL paradigm has a greater impact on critical thinking skills in terms of intellectual stimulation than traditional approaches. Moreover, using PBL, students can connect and synthesize each idea within a real-world scenario.

The world has experienced great challenges with the coronavirus pandemic (COVID-19) of unparalleled magnitude beginning the first half of 2020. Educators used creative methods such as online lectures, tutorials, and webinars to sustain the learning process whilst students stayed at home. COVID-19 transformed the education process, with the result that PBL methods were adapted for online distance learning to promote students' critical thinking skills (Chan et al., 2022; Chia et al., 2021). As discovered by Hidayati et al. (2020), online tools, such as 
digital mind maps can enhance students' critical thinking, as well as improve knowledge dissemination. PBL methods in educational pedagogies can improve graduates' soft skills, such as self-awareness, commitment, adaptability, behavior, courage, humanity, trustworthiness, consciousness, management, problemsolving, risk-taking, self-discipline, organizational awareness, as well as critical thinking abilities (Suryanti \& Supeni, 2019).

In some studies, such as Lisniandila et al. (2019), it was found that PBL may not be very effective in developing critical thinking skills when students are accustomed to conventional methods, especially in science subjects. However, recent developments in science education at a tertiary level has seen a greater implementation of PBL as a student-centered active learning model, especially in medicine (Foo et al., 2021), nursing science (Boleng et al., 2017; Hidayati et al., 2020; Saputro et al., 2020), mathematics and engineering (Hsu, 2021). Nevertheless, research studies on PBL in the social sciences published in highimpact journals are relatively scarce in the Web of Science, Scopus, and ProQuest databases as compared to pure sciences. As such, Ulger (2018) suggested that future research should explore the adoption of PBL method in a variety of educational disciplines to understand how it enhances students' critical thinking skills, as well as their creative thinking. This call has promoted more research into the application of PBL in social sciences curricula, such as economic studies (Corral-Lage et al., 2021), Islamic studies (Hashim \& Samsudin, 2020), visual arts (Ulger, 2018), civic education (Suarniati et al., 2019), and counselling studies (Suryanti \& Supeni, 2019).

Based on the surge of interest to explore the application of PBL in educational pedagogies to advance students' critical thinking, and the limited evaluative work in the social sciences literature, it is crucial to examine PBL in various educational disciplines with various student populations to determine the effectiveness of this pedagogical approach. Therefore, the objective of this study has been to produce an extensive mapping of themes related to problem-solving education and critical thinking skills in social sciences for the reference of future research.

\section{Material and Method}

A scoping review is a knowledge synthesis that examines the scope and character of research efforts with respect to a certain issue through the mapping of main concepts, themes, and main references, and can be established as a kind of evidence for a certain area of knowledge (Armstrong et al., 2011; Rumrill et al., 2010; Ramdan et al., 2021). This type of literature evaluation is specifically beneficial for specialized topics that have not been fully explored previously (Ganann et al., 2010). Furthermore, a scoping review has more flexibility than a typical systematic review or meta-analysis since it may account for a wide range of relevant literature and studies employing various techniques, which is not possible in a traditional review (Peterson et al., 2016; Arksey \& O'Malley, 2005).

This scoping review applied the five-stage process which was outlined by Arksey and O'Malley (2005) and later expanded by Levac et al. (2010) to: (1) identify research questions; (2) identify relevant studies; (3) remove redundant articles; (4) chart the data; and (5) collate, summarize, and report the results. 
The first stage involves the identification of the research questions. Two research questions are proposed for this scoping review. Firstly, what is the current state of the scientific literature on developing students' critical thinking skills using PBL? Secondly, what are the emerging themes in PBL for improving critical thinking abilities?

The second stage revolves around the identification of relevant studies. After identifying our research questions, a list of search terms was generated to characterize elements of improving critical thinking skills in teaching and PBL application among students, which have been shown in Table 1. Several types of search and retrieval trials were conducted across three interdisciplinary academic databases to refine search phrases (Web of Science, Scopus, and ProQuest).

The third stage involves screening to remove redundant articles. Table 2 shows several inclusion and exclusion criteria. Only research articles were selected since articles offer a more rigorous analysis of the subject and most studies are published in proceedings. Hence, the primary source of analytical evidence was research articles. However, articles on systematic review, meta-synthesis, meta-analysis, chapters in books, and newspapers were also excluded from the study. In terms of language, English articles published between 2016 and 2021 were included. To focus on PBL as a teaching pedagogy for social sciences, articles from medical engineering, computer science, energy, psychology, and decision sciences were not selected to avoid irrelevant articles or proceeding papers.

The fourth stage involves the data extraction or charting the data. Specifically, the data collected were summarized using the Microsoft Excel application to assist in the thematic and comparative analysis. The author's details, publication year, research method, constructs or variables, results, and themes have been included in Table 3.

Finally, the fifth stage entails gathering, summarizing, and reporting the findings. At this stage, common themes and conclusions from the publications were determined. Other important details, such as the origin of the study, publication year, and any other significant documentation, were also discussed at this stage.

Table 1: The search strings

\begin{tabular}{|c|c|}
\hline \multicolumn{2}{|c|}{ Database search string } \\
\hline $\begin{array}{l}\text { Web of } \\
\text { Science }\end{array}$ & $\begin{array}{l}\text { All fields } \\
\text { "problem-based learning" OR "active learning" } \\
\text { AND } \\
\text { "education" AND "critical thinking skill" } \\
\text { OR } \\
\text { "analytical thinking skill" }\end{array}$ \\
\hline Scopus & $\begin{array}{l}\text { TITLE-ABS-KEY "problem-based learning" } \\
\text { OR } \\
\text { "active learning" } \\
\text { "education" AND "critical thinking skill" } \\
\text { OR } \\
\text { "analytical thinking skill" }\end{array}$ \\
\hline
\end{tabular}




\begin{tabular}{|l|l|}
\hline \multirow{3}{*}{ ProQuest } & $\begin{array}{l}\text { "problem-based learning" } \\
\text { "active learning" AND "education" } \\
\text { "critical thinking skill" } \\
\\
\text { "analytical thinking skill" }\end{array}$ \\
\hline
\end{tabular}

Table 2: The inclusion and exclusion criteria

\begin{tabular}{|l|l|l|}
\hline Criterion & \multicolumn{1}{|c|}{ Eligibility } & \multicolumn{1}{c|}{ Exclusion } \\
\hline Literature & Journal (research articles) & $\begin{array}{l}\text { Systematic review, meta- } \\
\text { synthesis, meta-analysis, } \\
\text { chapters in books, and } \\
\text { newspapers }\end{array}$ \\
\hline Language & English & Other than English \\
\hline Timeline & $2016-2021$ & Earlier than 2016 \\
\hline $\begin{array}{l}\text { Subject } \\
\text { area }\end{array}$ & $\begin{array}{l}\text { Economics, Econometrics, } \\
\text { Finance, Business, } \\
\text { Accounting, Management } \\
\text { and, Social Sciences }\end{array}$ & $\begin{array}{l}\text { Other than Economics, } \\
\text { Econometrics, Finance, } \\
\text { Business, Accounting, } \\
\text { Management and, Social } \\
\text { Sciences }\end{array}$ \\
\hline
\end{tabular}

\section{Findings}

The database search extracted 884 articles based on the above-mentioned search techniques. Due to duplication, 77 of these articles were omitted from the initial list. A total of five hundred papers were then excluded based on the title and abstract due to methodology, publication type, language, timeline, and subject. After a thorough analysis of the remaining 307 papers, 287 were eliminated due to apparent irrelevancy to the scoping study's objective. Only 20 publications were selected after a thorough selection process based on the Preferred Reporting Items for Systematic Review, which is known as PRISMA, adapted by Moher et al. (2015) (See Figure 1). 


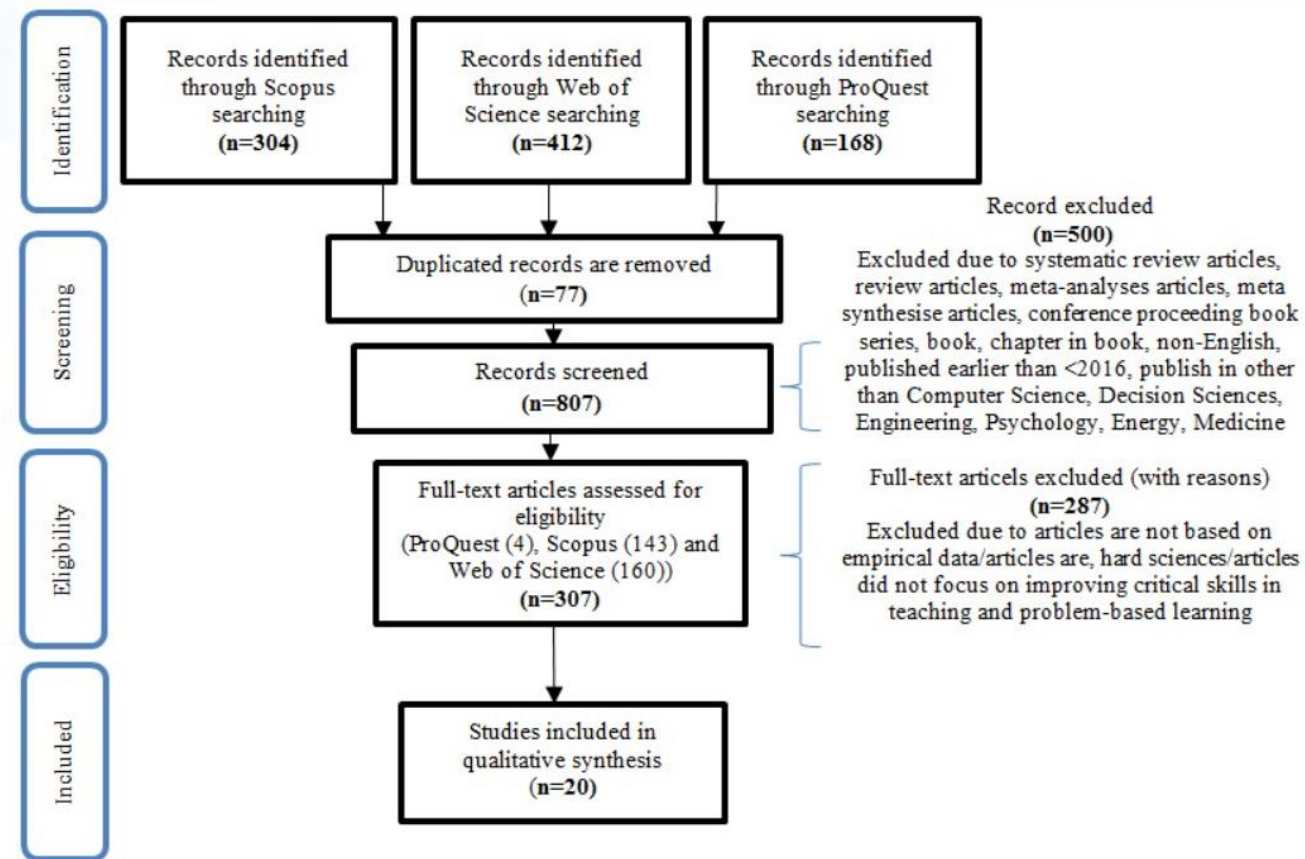

Figure 1: PRISMA flow diagram of the study selection process

Additionally, the selection of articles was limited to quantitative, qualitative, and mixed empirical studies from journal articles published during a six year period. Firstly, conference proceedings were excluded due to a lack of systematization and openness because of conventional evaluations (Hodgkinson \& Ford, 2014). Secondly, research on a specific issue that has been conducted for at least six years shows the stability of the subject (Kraus et al., 2020). As a result, it was pertinent for this study to select high-quality articles within the recent six year period to perform a scoping review.

\subsection{Main Findings}

Table 3 highlights the twenty articles which were selected based on the required criteria as mentioned. Basically, there were fifteen quantitative studies (Carvalho, 2016; Foo et al., 2021; Garnjost \& Lawter, 2019; Geitz et al., 2016; Hashima \& Samsudin, 2020; Hidayati et al., 2019, 2020; Lisniandila et al., 2019; Oderinu et al., 2020; Saiful et al., 2020; Saputra et al., 2019; Saputro et al., 2020; Suarniati et al., 2019; Ulger, 2018; Yağc1, 2018); three qualitative studies (Blackburn, 2017; Heaviside et al., 2018; Suryanti \& Supeni, 2019); and two mixed method studies (Ioannou et al., 2016; Ismail et al., 2018).

The majority of the studies $(n=8)$ were conducted in Indonesia (Hidayati et al., 2019, 2020; Lisniandila et al., 2019; Saiful et al., 2020; Saputra et al., 2019; Saputro et al., 2020; Suarniati et al., 2019; Suryanti \& Supeni, 2019), followed by the United Kingdom $(n=3)$ (Geitz et al., 2016; Heaviside et al., 2018; Ioannou et al., 2016), Turkey $(n=2)$ (Ulger, 2018; Yağc1, 2018) and Malaysia $(n=2)$ (Hashima \& Samsudin, 2020; Ismail et al., 2018). In addition, just one study on PBL $(n=1)$ has been conducted in the United States (Garnjost \& Lawter, 2019), Germany (Blackburn, 
2017), Portugal (Carvalho, 2016), Hong Kong (Foo et al., 2021), and Nigeria (Oderinu et al., 2020) respectively.

Furthermore, nine subthemes were identified under four major headings from the scoping review. The major headings are human capital, learning environment, process, and content. Firstly, in terms of human capital, the problems were mostly focused on the student's attitude and conduct (Geitz et al., 2016; Yağcl, 2018) in the learning environment. Secondly, the learning environment addressed the key problems in PBL application such as the difficulty in communication linked to PBL dynamics (Heaviside et al., 2018) and the initiative to promote individual learning (Ismail et al., 2018; Hidayati et al., 2019), which justified its effective usage. Thirdly, processes discussed in recent studies included the definition of educational objectives and goals; awareness of constructivist pedagogy and its effects on the learning strategy; the stimulation of student regulation and selfefficiency through continuous feedback (Blackburn, 2017); and the coordination of projects carried out by student teams (Saputro et al., 2020). The final main heading encompassed issues related to the sharing of information and references to the learning environment, and the development of unconventional teaching materials to support PBL (Suarniati et al., 2019; Hashima \& Samsudin, 2020), as well as the requirement for multiple interconnected courses (Oderinu et al., 2020), many of which go beyond course planning, in order to effectively solve problems. 
Table 3: Data charting form

\begin{tabular}{|c|c|c|c|c|}
\hline $\begin{array}{l}\text { Publication } \\
\text { and Research } \\
\text { Method }\end{array}$ & Aim & $\begin{array}{l}\text { Construct/ } \\
\text { Variables }\end{array}$ & Results & Theme \\
\hline $\begin{array}{l}\text { Garnjost and } \\
\text { Lawter (2019) } \\
\text { Quantitative } \\
\text { study }\end{array}$ & $\begin{array}{l}\text { To determine } \\
\text { whether student- } \\
\text { centered } \\
\text { pedagogies are } \\
\text { better than } \\
\text { instructor- } \\
\text { centered } \\
\text { pedagogies in } \\
\text { relation to } \\
\text { perceived } \\
\text { learning } \\
\text { outcomes and } \\
\text { student } \\
\text { satisfaction. }\end{array}$ & $\begin{array}{l}\text { Independent: } \\
\text { problem-solving, } \\
\text { self-directed } \\
\text { learning, } \\
\text { knowledge } \\
\text { acquisition, critical } \\
\text { thinking, student } \\
\text { satisfaction. } \\
\text { Dependent: } \\
\text { student-focused } \\
\text { teaching style } \\
\text { rather than } \\
\text { instructor-focused } \\
\text { teaching style. }\end{array}$ & $\begin{array}{l}\text { When compared to } \\
\text { the lecture method, } \\
\text { PBL had no effect on } \\
\text { critical thinking or } \\
\text { self-directed } \\
\text { learning. } \\
\text { Additionally, there } \\
\text { were no significant } \\
\text { differences in } \\
\text { perceived learning } \\
\text { outcomes between } \\
\text { other pedagogies } \\
\text { and the lecture } \\
\text { method. Student } \\
\text { satisfaction was } \\
\text { higher in PBL. }\end{array}$ & $\begin{array}{l}\text { Perceived } \\
\text { learning's } \\
\text { impact on } \\
\text { satisfaction }\end{array}$ \\
\hline $\begin{array}{l}\text { Ulger (2018) } \\
\text { Quantitative } \\
\text { study }\end{array}$ & $\begin{array}{l}\text { To assess the } \\
\text { effect of PBL on } \\
\text { the creative and } \\
\text { critical thinking } \\
\text { skills of learners. }\end{array}$ & $\begin{array}{l}\text { Independent: } \\
\text { creative thinking, } \\
\text { critical thinking, } \\
\text { disposition, } \\
\text { inventory. } \\
\text { Dependent: } \\
\text { between subjects. }\end{array}$ & $\begin{array}{l}\text { PBL can assist } \\
\text { students with non- } \\
\text { routine problem- } \\
\text { solving by } \\
\text { improving creative } \\
\text { thinking. }\end{array}$ & $\begin{array}{l}\text { PBL on } \\
\text { critical } \\
\text { thinking } \\
\text { skills }\end{array}$ \\
\hline $\begin{array}{l}\text { Ismail et al. } \\
(2018) \\
\text { Mixed method } \\
\text { study }\end{array}$ & $\begin{array}{l}\text { To assess the PBL } \\
\text { environment's } \\
\text { integration into } \\
\text { the process of } \\
\text { designing and } \\
\text { developing } \\
\text { mobile } \\
\text { applications for } \\
\text { learning scientific } \\
\text { terms and } \\
\text { explore how the } \\
\text { app helps } \\
\text { students to think } \\
\text { critically. }\end{array}$ & $\begin{array}{l}\text { Independent: } \\
\text { apps for learning } \\
\text { scientific terms. } \\
\text { Dependent: critical } \\
\text { thinking skill. }\end{array}$ & $\begin{array}{l}\text { A positive effect } \\
\text { could be seen on the } \\
\text { students' critical } \\
\text { thinking with the } \\
\text { usage of the app. } \\
\text { Qualitative analysis } \\
\text { data covered four } \\
\text { features in the app } \\
\text { that enable students } \\
\text { to enhance their } \\
\text { critical thinking } \\
\text { skills. }\end{array}$ & $\begin{array}{l}\text { PBL on } \\
\text { critical } \\
\text { thinking } \\
\text { skills }\end{array}$ \\
\hline $\begin{array}{l}\text { Yağc1 (2018) } \\
\text { Quantitative } \\
\text { study }\end{array}$ & $\begin{array}{l}\text { To assess the } \\
\text { effect of learners' } \\
\text { study approaches } \\
\text { on their attitudes } \\
\text { towards } \\
\text { programming } \\
\text { and academic } \\
\text { achievement in } \\
\text { online PBL. }\end{array}$ & $\begin{array}{l}\text { Independent: } \\
\text { attitudes toward } \\
\text { programming, } \\
\text { academic } \\
\text { achievement. } \\
\text { Dependent: } \\
\text { online PBL }\end{array}$ & $\begin{array}{l}\text { Learners who } \\
\text { adopted the "deep" } \\
\text { study approach } \\
\text { were more } \\
\text { successful than } \\
\text { those who adopted a } \\
\text { "superficial" } \\
\text { approach. The PBL } \\
\text { application affects } \\
\text { the learners' } \\
\text { attitudes positively } \\
\text { toward } \\
\text { programming, but } \\
\text { the study approach } \\
\text { did not significantly } \\
\text { affect learners' } \\
\text { attitudes toward } \\
\text { programming. }\end{array}$ & $\begin{array}{l}\text { PBL on } \\
\text { attitude }\end{array}$ \\
\hline
\end{tabular}




\begin{tabular}{|c|c|c|c|c|}
\hline $\begin{array}{l}\text { Heaviside et } \\
\text { al. (2018) } \\
\text { Qualitative } \\
\text { study }\end{array}$ & $\begin{array}{l}\text { To analyze the } \\
\text { role of PBL in } \\
\text { developing } \\
\text { employability } \\
\text { skills. }\end{array}$ & & $\begin{array}{l}\text { PBL played a major } \\
\text { role in developing } \\
\text { employability skills } \\
\text { such as teamwork, } \\
\text { communication, and } \\
\text { interpersonal skills, } \\
\text { critical and creative } \\
\text { thinking, and } \\
\text { flexibility. }\end{array}$ & $\begin{array}{l}\text { PBL in the } \\
\text { developmen } \\
t \text { of generic } \\
\text { skills }\end{array}$ \\
\hline $\begin{array}{l}\text { Hidayati et al. } \\
(2019) \\
\text { Qualitative } \\
\text { study }\end{array}$ & $\begin{array}{l}\text { How is the } \\
\text { adoption of PBL } \\
\text { in university } \\
\text { aligned to the } \\
\text { eLearning } \\
\text { environment? }\end{array}$ & & $\begin{array}{l}\text { Feedback from } \\
\text { students was very } \\
\text { positive. The } \\
\text { students commented } \\
\text { on its realism and on } \\
\text { how they enjoyed } \\
\text { the simulation of an } \\
\text { online problem. } \\
\text { Nonetheless, major } \\
\text { challenges were met } \\
\text { in the } \\
\text { implementation } \\
\text { which required } \\
\text { several support } \\
\text { across the } \\
\text { organization. }\end{array}$ & $\begin{array}{l}\text { PBL in a } \\
\text { virtual } \\
\text { learning } \\
\text { context }\end{array}$ \\
\hline $\begin{array}{l}\text { Carvalho } \\
(2016) \\
\text { Quantitative } \\
\text { study }\end{array}$ & $\begin{array}{l}\text { To assess the } \\
\text { effectiveness of } \\
\text { PBL in } \\
\text { inculcating } \\
\text { transferable } \\
\text { skills. }\end{array}$ & $\begin{array}{l}\text { Independent: } \\
\text { positive assessment } \\
\text { experience, } \\
\text { subscribing } \\
\text { assessment rules, } \\
\text { defining teamwork } \\
\text { rules, problems } \\
\text { with teamwork, } \\
\text { problems in } \\
\text { managing time, } \\
\text { interaction with the } \\
\text { tutor, problems } \\
\text { with the host } \\
\text { company, } \\
\text { understanding how } \\
\text { organizations } \\
\text { work, imagining } \\
\text { future professional } \\
\text { life. Dependent: } \\
\text { satisfaction, skill } \\
\text { development. }\end{array}$ & $\begin{array}{l}\text { PBL implementation } \\
\text { had a direct effect on } \\
\text { satisfaction and skill } \\
\text { development. The } \\
\text { factors concerning } \\
\text { the assessment } \\
\text { experience and } \\
\text { assessment rules } \\
\text { contribute only } \\
\text { towards student } \\
\text { satisfaction. In } \\
\text { addition, interaction } \\
\text { with the tutor, } \\
\text { problems with the } \\
\text { company, and being } \\
\text { able to imagine a } \\
\text { professional future } \\
\text { directly affect skills } \\
\text { development. }\end{array}$ & $\begin{array}{l}\text { PBL in the } \\
\text { developmen } \\
t \text { of generic } \\
\text { skills }\end{array}$ \\
\hline $\begin{array}{l}\text { Geitz et al. } \\
(2016) \\
\text { Quantitative } \\
\text { study }\end{array}$ & $\begin{array}{l}\text { To explore the } \\
\text { relationship } \\
\text { between self- } \\
\text { efficacy, learning } \\
\text { behavior, and } \\
\text { performance of } \\
\text { students. }\end{array}$ & $\begin{array}{l}\text { Independent: } \\
\text { self-efficacy, } \\
\text { learning behavior, } \\
\text { sustainable } \\
\text { feedback. } \\
\text { Dependent: } \\
\text { performance } \\
\text { outcomes. }\end{array}$ & $\begin{array}{l}\text { Surface learning } \\
\text { showed a negative } \\
\text { effect on } \\
\text { performance } \\
\text { outcomes. However, } \\
\text { self-efficacy had a } \\
\text { positive influence. } \\
\text { Deep learning was } \\
\text { found to be a strong } \\
\text { indicator of self- } \\
\text { efficacy. The } \\
\text { experimental group } \\
\text { and the control }\end{array}$ & $\begin{array}{l}\text { PBL on } \\
\text { learning } \\
\text { behavior }\end{array}$ \\
\hline
\end{tabular}




\begin{tabular}{|c|c|c|c|c|}
\hline & & & $\begin{array}{l}\text { group showed } \\
\text { significant gains in } \\
\text { self-efficacy and } \\
\text { surface learning. }\end{array}$ & \\
\hline $\begin{array}{l}\text { Foo et al. } \\
(2021) \\
\text { Quantitative } \\
\text { study }\end{array}$ & $\begin{array}{l}\text { To compare the } \\
\text { performance of } \\
\text { learners using } \\
\text { distance learning } \\
\text { PBL tutorials and } \\
\text { students using } \\
\text { the conventional } \\
\text { face-to-face } \\
\text { approach. }\end{array}$ & $\begin{array}{l}\text { Independent: } \\
\text { distance learning, } \\
\text { face-to-face } \\
\text { approach. } \\
\text { Dependent: } \\
\text { learners' } \\
\text { performance }\end{array}$ & $\begin{array}{l}\text { The distance } \\
\text { learning group had } \\
\text { significantly lower } \\
\text { scores than the face- } \\
\text { to-face approach } \\
\text { group particularly in } \\
\text { participating, } \\
\text { communicating, } \\
\text { preparing, critical } \\
\text { thinking, and group } \\
\text { skills. }\end{array}$ & $\begin{array}{l}\text { PBL on } \\
\text { critical } \\
\text { thinking } \\
\text { skill }\end{array}$ \\
\hline $\begin{array}{l}\text { Saiful et al. } \\
(2020) \\
\text { Quantitative } \\
\text { study }\end{array}$ & $\begin{array}{l}\text { To assess the PBL } \\
\text { model on } \\
\text { learners' critical } \\
\text { thinking skills } \\
\text { and } \\
\text { environmental } \\
\text { attitude. }\end{array}$ & $\begin{array}{l}\text { Independent: } \\
\text { PBL model. } \\
\text { Dependent: } \\
\text { learners' critical } \\
\text { thinking skills, } \\
\text { learners' } \\
\text { environmental } \\
\text { attitude. }\end{array}$ & $\begin{array}{l}\text { The PBL model } \\
\text { showed significant } \\
\text { influence on } \\
\text { learners' critical } \\
\text { thinking skills. It } \\
\text { also had a } \\
\text { significant influence } \\
\text { on learners' } \\
\text { environmental } \\
\text { attitudes. PBL } \\
\text { showed a higher } \\
\text { impact on critical } \\
\text { thinking skills and } \\
\text { environmental } \\
\text { attitudes than the } \\
\text { conventional } \\
\text { learning model. }\end{array}$ & $\begin{array}{l}\text { PBL on } \\
\text { critical } \\
\text { thinking } \\
\text { skill }\end{array}$ \\
\hline $\begin{array}{l}\text { Oderinu et al. } \\
(2020) \\
\text { Quantitative } \\
\text { study }\end{array}$ & $\begin{array}{l}\text { To evaluate the } \\
\text { perceptions of } \\
\text { PBL compared to } \\
\text { the conventional } \\
\text { lecture method. }\end{array}$ & $\begin{array}{l}\text { Independent: } \\
\text { PBL, traditional } \\
\text { teaching. } \\
\text { Dependent: } \\
\text { teaching method. }\end{array}$ & $\begin{array}{l}\text { A significant } \\
\text { difference could be } \\
\text { seen between PBL } \\
\text { and conventional } \\
\text { teaching methods } \\
\text { for all the perceived } \\
\text { factors. The mean } \\
\text { score for most of the } \\
\text { perception items is } \\
\text { higher in the PBL } \\
\text { method as } \\
\text { compared to } \\
\text { conventional } \\
\text { teaching. }\end{array}$ & $\begin{array}{l}\text { Instructional } \\
\text { approach to } \\
\text { critical } \\
\text { thinking } \\
\text { skills }\end{array}$ \\
\hline $\begin{array}{l}\text { Hidayati et al. } \\
(2020) \\
\text { Quantitative } \\
\text { study }\end{array}$ & $\begin{array}{l}\text { To determine the } \\
\text { correlation } \\
\text { between critical } \\
\text { thinking and } \\
\text { knowledge } \\
\text { acquisition in the } \\
\text { implementation } \\
\text { of digital mind } \\
\text { maps-PBL. }\end{array}$ & $\begin{array}{l}\text { Independent: } \\
\text { critical thinking. } \\
\text { Dependent: } \\
\text { knowledge } \\
\text { acquisition. }\end{array}$ & $\begin{array}{l}\text { There was a } \\
\text { correlation between } \\
\text { critical thinking and } \\
\text { knowledge } \\
\text { acquisition. The } \\
\text { conclusion was that } \\
\text { digital mind maps- } \\
\text { PBL strategies can } \\
\text { be applied to } \\
\text { promote learners' } \\
\text { critical thinking, } \\
\text { which may cause } \\
\text { improvement in }\end{array}$ & $\begin{array}{l}\text { PBL on } \\
\text { critical } \\
\text { thinking } \\
\text { skills }\end{array}$ \\
\hline
\end{tabular}




\begin{tabular}{|c|c|c|c|c|}
\hline & & & $\begin{array}{l}\text { learners' knowledge } \\
\text { acquisition. }\end{array}$ & \\
\hline $\begin{array}{l}\text { Hashima \& } \\
\text { Samsudin } \\
(2020) \\
\text { Quantitative } \\
\text { study }\end{array}$ & $\begin{array}{l}\text { To identify the } \\
\text { perceptions of } \\
\text { selected public } \\
\text { universities } \\
\text { lecturers on the } \\
\text { implementation } \\
\text { of PBL. }\end{array}$ & $\begin{array}{l}\text { Independent: } \\
\text { satisfaction with } \\
\text { the implementation } \\
\text { of PBL, } \\
\text { improvement of } \\
\text { learners' soft skills } \\
\text { through PBL, } \\
\text { effective } \\
\text { implementation of } \\
\text { PBL by the lecturer, } \\
\text { suitability of } \\
\text { implementing PBL. } \\
\text { Dependent: } \\
\text { Islamic studies' } \\
\text { courses. }\end{array}$ & $\begin{array}{l}\text { The use of PBL in } \\
\text { public institutions } \\
\text { indicates a positive } \\
\text { attitude toward } \\
\text { learning. Lecturers } \\
\text { view PBL positively } \\
\text { because they can } \\
\text { relate classroom } \\
\text { learning to real-life } \\
\text { situations. }\end{array}$ & $\begin{array}{l}\text { Perceived } \\
\text { learning's } \\
\text { impact on } \\
\text { satisfaction }\end{array}$ \\
\hline $\begin{array}{l}\text { Saputro et al. } \\
(2020) \\
\text { Quantitative } \\
\text { study }\end{array}$ & $\begin{array}{l}\text { To explore effects } \\
\text { of PBL on trainee } \\
\text { teachers' self- } \\
\text { efficacy and } \\
\text { critical thinking. }\end{array}$ & $\begin{array}{l}\text { Independent: } \\
\text { self-efficacy scales, } \\
\text { critical thinking. } \\
\text { Dependent: } \\
\text { experimental, } \\
\text { control groups. }\end{array}$ & $\begin{array}{l}\text { PBL was more } \\
\text { effective than } \\
\text { traditional learning } \\
\text { in increasing self- } \\
\text { efficacy and critical } \\
\text { thinking of trainee } \\
\text { teachers. }\end{array}$ & $\begin{array}{l}\text { Self- } \\
\text { efficiency } \\
\text { through PBL }\end{array}$ \\
\hline $\begin{array}{l}\text { Saputra et al. } \\
\text { (2019) } \\
\text { Quantitative } \\
\text { study }\end{array}$ & $\begin{array}{l}\text { To assess the } \\
\text { effectiveness of } \\
\text { collaboration of } \\
\text { jigsaw and PBL } \\
\text { model in } \\
\text { developing } \\
\text { learners' critical } \\
\text { thinking skills. }\end{array}$ & $\begin{array}{l}\text { Independent: } \\
\text { collaboration of } \\
\text { jigsaw and PBL } \\
\text { model. Dependent: } \\
\text { critical thinking } \\
\text { skills. }\end{array}$ & $\begin{array}{l}\text { The usage of the } \\
\text { collaboration of } \\
\text { jigsaw and the PBL } \\
\text { models showed } \\
\text { significant results in } \\
\text { developing learners' } \\
\text { critical thinking } \\
\text { skills. }\end{array}$ & $\begin{array}{l}\text { PBL on } \\
\text { critical } \\
\text { thinking } \\
\text { skills }\end{array}$ \\
\hline $\begin{array}{l}\text { Suarniati et al. } \\
(2019) \\
\text { Quantitative } \\
\text { study }\end{array}$ & $\begin{array}{l}\text { To compare the } \\
\text { impact of PBL } \\
\text { and traditional } \\
\text { learning methods } \\
\text { on critical } \\
\text { thinking skills. }\end{array}$ & $\begin{array}{l}\text { Independent: } \\
\text { critical thinking } \\
\text { skills. } \\
\text { Dependent: } \\
\text { conventional } \\
\text { learning strategy } \\
\text { implementation. }\end{array}$ & $\begin{array}{l}\text { There was a } \\
\text { significant difference } \\
\text { between the effects } \\
\text { of PBL and } \\
\text { traditional learning } \\
\text { approach on the } \\
\text { critical thinking } \\
\text { skills of vocational } \\
\text { school students in } \\
\text { civic education } \\
\text { subjects. }\end{array}$ & $\begin{array}{l}\text { Instructional } \\
\text { approach to } \\
\text { critical } \\
\text { thinking } \\
\text { skills }\end{array}$ \\
\hline $\begin{array}{l}\text { Hidayati et al. } \\
(2019) \\
\text { Quantitative } \\
\text { study }\end{array}$ & $\begin{array}{l}\text { To analyze the } \\
\text { relationship } \\
\text { between critical } \\
\text { thinking and } \\
\text { creativity skills } \\
\text { through the } \\
\text { integration of } \\
\text { PBL and the } \\
\text { digital mind } \\
\text { maps learning } \\
\text { model. }\end{array}$ & $\begin{array}{l}\text { Independent: } \\
\text { critical thinking. } \\
\text { Dependent: } \\
\text { creativity. }\end{array}$ & $\begin{array}{l}\text { A significant } \\
\text { relationship could } \\
\text { be seen between } \\
\text { critical thinking and } \\
\text { creativity. To } \\
\text { conclude, the } \\
\text { integration of PBL } \\
\text { and the digital mind } \\
\text { maps model is an } \\
\text { alternative approach } \\
\text { to empower the } \\
\text { learners' critical } \\
\text { thinking and } \\
\text { creativity. }\end{array}$ & $\begin{array}{l}\text { Integrated/b } \\
\text { lended PBL } \\
\text { for critical } \\
\text { thinking } \\
\text { skills and } \\
\text { creativity }\end{array}$ \\
\hline
\end{tabular}




\begin{tabular}{|c|c|c|c|c|}
\hline $\begin{array}{l}\text { Lisniandila et } \\
\text { al. (2019) } \\
\text { Quantitative } \\
\text { study }\end{array}$ & $\begin{array}{l}\text { To assess the } \\
\text { effect of PBL } \\
\text { teaching } \\
\text { approach and } \\
\text { direct instruction } \\
\text { approach on } \\
\text { learners' critical } \\
\text { thinking skills. }\end{array}$ & $\begin{array}{l}\text { Independent: } \\
\text { PBL teaching } \\
\text { method, direct } \\
\text { instruction method. } \\
\text { Dependent: } \\
\text { students' critical } \\
\text { thinking skills. }\end{array}$ & $\begin{array}{l}\text { A critical thinking } \\
\text { skills gap was } \\
\text { discovered between } \\
\text { the learners using } \\
\text { PBL and those using } \\
\text { the direct instruction } \\
\text { approach. The PBL } \\
\text { group had a higher } \\
\text { average critical } \\
\text { thinking skills score } \\
\text { (post-test) as } \\
\text { compared to the } \\
\text { direct instruction } \\
\text { method group's } \\
\text { scores. }\end{array}$ & $\begin{array}{l}\text { Instructional } \\
\text { approach to } \\
\text { critical } \\
\text { thinking } \\
\text { skills }\end{array}$ \\
\hline $\begin{array}{l}\text { Suryanti \& } \\
\text { Supeni (2019) } \\
\text { Qualitative } \\
\text { study }\end{array}$ & $\begin{array}{l}\text { Ways to improve } \\
\text { learners' soft } \\
\text { skills through } \\
\text { PBL to develop } \\
\text { superior human } \\
\text { resources. }\end{array}$ & - & $\begin{array}{l}\text { PBL in education } \\
\text { can improve } \\
\text { learners' soft skills } \\
\text { to develop strong } \\
\text { human resources. }\end{array}$ & $\begin{array}{l}\text { PBL in the } \\
\text { developmen } \\
t \text { of generic } \\
\text { skills }\end{array}$ \\
\hline $\begin{array}{l}\text { Ioannou et al. } \\
(2016) \\
\text { Mixed method } \\
\text { study }\end{array}$ & $\begin{array}{l}\text { Using PBL in a } \\
\text { multi-model, } \\
\text { technology-rich } \\
\text { classroom and } \\
\text { presentation of } \\
\text { evaluation data } \\
\text { on students' } \\
\text { technology } \\
\text { adoption } \\
\text { experience while } \\
\text { engaging in PBL. }\end{array}$ & $\begin{array}{l}\text { Independent: } \\
\text { communication } \\
\text { and interaction, } \\
\text { reflection, } \\
\text { perceived learning, } \\
\text { satisfaction, } \\
\text { frustration. }\end{array}$ & $\begin{array}{l}\text { The learners were } \\
\text { positive about the } \\
\text { learning } \\
\text { environment. } \\
\text { Furthermore, } \\
\text { quantitative content } \\
\text { analysis of Facebook } \\
\text { users demonstrated } \\
\text { how the physical } \\
\text { and digital tools in } \\
\text { the environment, } \\
\text { combined with } \\
\text { Facebook's } \\
\text { capability as a } \\
\text { recordkeeping and } \\
\text { communication tool, } \\
\text { played an important } \\
\text { role in the PBL } \\
\text { process. }\end{array}$ & $\begin{array}{l}\text { PBL in the } \\
\text { developmen } \\
\text { t of generic } \\
\text { skills }\end{array}$ \\
\hline
\end{tabular}

\section{Discussion}

The PBL approach has helped in the creation of soft skills such as critical thinking, problem-solving, self-directed learning, the ability to adapt, communication skills, interpersonal skills, and teamwork skills. These skills have been grouped together as two categories of higher-level skills, namely intellectual and cooperative abilities (Meister, 2020). The COVID-19 pandemic has caused many changes in the modern world. All these require new attitudes and behaviors which can shape our lives, such as developing the ability to learn through problem-solving (Bird, 2020) in PBL and engaging with topics that build critical thinking skills.

The aims of PBL, as discussed by Barrows and Tamblyn (1980), are relevant $21^{\text {st }}$ century teaching and learning. This is because the aims are in line with the list of skills needed by today's students. Zmuda (2009) identified the following essential $21^{\text {st }}$ century skills: (a) critical thinking, (b) problem solving, (c) collaborative skills, 
(d) effective communication, and (e) global literacy. The skills mentioned are related to and in line with the PBL aims as stated by Barrows and Tamblyn (1980). The challenge is to upgrade skills and learning in the current situation, and to develop graduates who can fulfil the human resource requirements within a globalized world based on technology. The PBL approach is a very appropriate method to achieve this.

Moreover, the scoping analysis shows that most of the current research on critical thinking skills in PBL teaching can be classified into four key categories. In a PBL setting, human capital extends beyond the roles of teacher and student (Geitz et al., 2016; Yağc1, 2018). This is because PBL requires the involvement of both parties, thus fostering a positive learning environment through the implementation of projects developed by students under the guidance of the teacher, who serves as tutor and facilitator. As mentioned by Hidayati et al. (2019, 2020) and Ioannou et al. (2016), it is nearly impossible to discuss the learning environment in the PBL method without mentioning collaboration. It is therefore crucial to highlight that PBL allows more rigorous and regulated processes through the collaborative work and multifunctional teams, which necessitates the use of more complex management processes and extra attention to working group creation.

In recent years, a review of the studies revealed a particular interest in the processes involved in the PBL environment, particularly the student evaluation process for technical and soft skills (Blackburn, 2017). In this context, it is critical to support the development of students' self-efficiency by establishing methods that motivate them to regulate and take responsibility for their learning (Saputro et al., 2020). More evidence on teaching and learning processes shows that the use of active learning methods and technology is highly useful in adding dynamism to the setting (Shi et al., 2019; Coorey, 2016). The objective of PBL is not to produce material in a normal sense; the teacher becomes the curator of the learning material by choosing acceptable subjects for the educational proposal, screening excellent information and references, and constructing a content base to achieve the learning objectives.

Figure 2 shows an overview of the theme that has been adapted from the overall findings. 


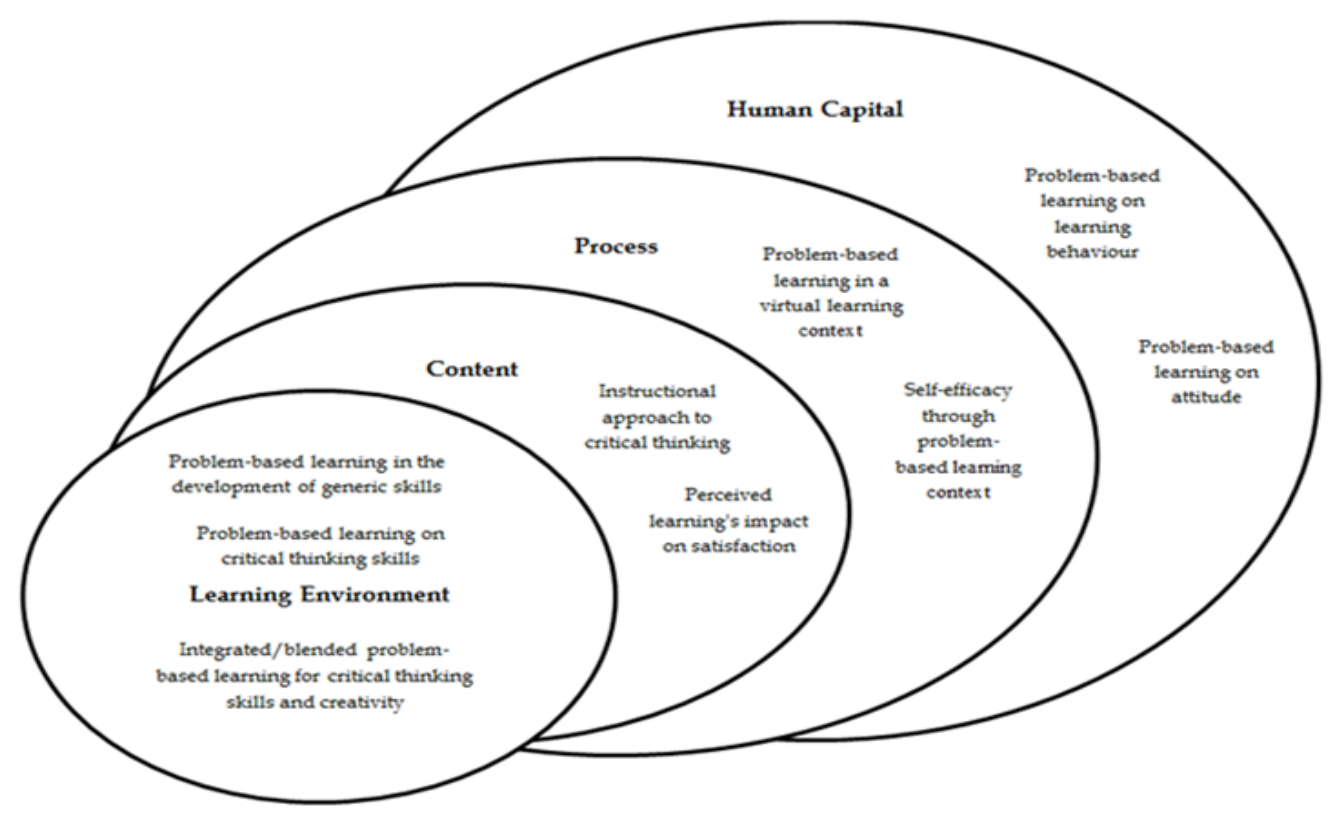

Figure 2: Framework on improving critical thinking skills in students using PBL teaching methods

\section{Implications of the Study}

This scoping review recommends that PBL is grounded in the key ideologies that are common to many theories of teaching and learning that can guide how PBL is executed in all educational programs. The ability to think through a problem should be the outcome of learning, and therefore problem-solving abilities must be learned (Sari et al., 2021). The approach encourages successful life-long learning and language acquisition, whereby learners start to see how the knowledge they learnt helps them to solve problems in life and become life-long learners. PBL develops self-directed learning skills for learners. Using this approach, learners work in a group to brainstorm the problem in an assignment; they define the problem and then clarify what they know and do not know about the material. Familiarizing PBL principles in the context of national culture and local educational institutions, as well as taking into consideration the characteristics of students and teachers, is vital for long-term implementation (Sabah \& Du, 2018).

The advantages of PBL have made this approach increasingly popular for many years (Md. Zabit et al., 2021). Despite the emergence of new norms following the COVID-19 pandemic, PBL plays a major role in relating theory and practice by involving students in the problem-solving process through simulation of the actual environment. The COVID-19 pandemic has pushed for more significant teaching and training to address needs in the workplace and society in all sectors. This professional development has always been unique regarding its academic approach in teaching and learning, as well as its training approach, where knowledge and skills are developed through 'learning by doing' (Miester, 2020). 


\section{Limitation and Recommendation}

Even though this study only looked at a restricted number of articles from the Web of Science, Scopus, and ProQuest databases, the trend suggests that an increase in the number of publications is imminent. This is because the topic of strengthening critical thinking skills in teaching through PBL has recently gained a lot more attention and concern from researchers. A wider range of data can be explored by searching databases such as Sage, Springer, Science Direct, and Taylor Francis. As suggested by Petrosino et al. (2002), future researchers can employ systematic literature reviews that can be defined as finding, integrating, and evaluating all accessible data produced in qualitative and quantitative studies to offer an observationally determined answer to a research inquiry. As a result, future research studies related to improving critical thinking skills in teaching through PBL may include more database resources. According to the findings of this study, future research may focus on in-depth investigations of PBL in the context of management learning experiences, problem-solving abilities, and practice-based education.

\section{Conclusion}

This research confirms that there are several options and techniques for enhancing critical thinking abilities in students through PBL. Based on the data examined, the PBL method in education enhances students' team involvement and learning capacity, provides opportunities to practice skills, educates professionals with a holistic vision, improves critical thinking, and increases capacity to deal with different market conditions. However, some issues were discovered in the formulation of problems, the high cost of a learning environment that is compatible with labor market realities, the development of non-traditional content, the definition of educational objectives, and their monitoring through assessment processes. This scoping review identifies four main themes and nine sub-themes related to the improvement of critical thinking skills in teaching through PBL. More comprehensive research is required to further investigate the impacts of PBL on student performance outcomes, especially in the social sciences, as well as performance in both academic and professional situations.

\section{Acknowledgements}

This research was funded by a GPUBP: 2020-0102-107-01 research grant from Universiti Pendidikan Sultan Idris.

\section{References}

Alvarez-Huerta, P., Muela, A., \& Larrea, I. (2022). Disposition toward critical thinking and creative confidence beliefs in higher education students: The mediating role of openness to diversity and challenge. Thinking Skills and Creativity, 43, 1-9. https://doi.org/10.1016/j.tsc.2022.101003

Amin, S., Sumarmi, S., Bachri, S., Susilo, S., \& Bashith, A. (2020). The effect of problembased hybrid learning (PBHL) models on spatial thinking ability and geography learning outcomes. International Journal of Emerging Technologies in Learning (iJET), 15(19), 83-94. https:// doi.org/10.3991/ijet.v15i19.15729

Arksey, H., \& O'Malley, L. (2005). Scoping studies: Towards a methodological framework. International Journal of Social Research Methodology, 8(1), 19-32. https://doi.org/10.1080/1364557032000119616 
Armstrong, R., Hall, B. J., Doyle, J., \& Waters, E. (2011). 'Scoping the scope' of a cochrane review. Journal of Public Health, 33(1), 147-150. https://doi.org/10.1093/pubmed/fdr015

Barrow, E. J., Lyte, G., \& Butterworth, T. (2002). An evaluation of problem-based learning in a nursing theory and practice module. Nurse Education in Practice, 2(1), 55-62. https://doi.org/10.1054/nepr.2002.0043

Barrows, H. S., \& Tamblyn, R. M. (1980). Problem-based learning: An approach to medical education. Springer Publishing Company.

Bird, D. (2020). Planning your post-COVID-19 return: 8 kinds of attitudes about risk, Enterprisers Project. The Enterprisers Project.

Blackburn, G. (2017). A university's strategic adoption process of an PBL-aligned eLearning environment: An exploratory case study. Educational Technology Research and Development, 65(1), 147-176. https://doi.org/10.1007/s11423-0169472-3

Boleng, D. T., Lumowa, S. V., Palenewen, E., \& Corebima, A. D. (2017). The effect of learning models on biology critical thinking skills of multiethnic students at senior high schools in Indonesia. Problems of Education in the 21st Century, 75(2), 1-8.

Carvalho, A. (2016). The impact of PBL on transferable skills development in management education. Innovations in Education and Teaching International, 53(1), 35-47. https:// doi.org/10.1080/14703297.2015.1020327

Caspary, M., \& Wickstrom, C. D. (2017). Multicultural Problem-based Learning Approaches Facilitate ESP Language Acquisition. International Journal of Learning, Teaching and Educational Research, 16(3), 1-14.

Chan, C. F., An, J. L, Che Rafidah, A., Wei, H. H., Vinod, P., Cockburn, J. G., Siti Nurjawahir, R., Kuhan, K., Prahaladhan, S., Noor Filzati, Z., \& Jamuna, V. (2022). Learning experiences of pre-clinical medical students in virtual problem-based learning amidst the COVID-19 pandemic. The Asia Pacific Scholar, 7(1), 33-43.

Chia, T. C., Chiao, L. T., Mong, W. L., Chih, W. Y., Chao, C. H., Huey, L. C., Chiun, H, \& Bor, C. S. (2021). Fully digital problem-based learning for undergraduate medical students during the COVID-19 period: Practical considerations. Journal of the Formosan Medical Association. https://doi.org/10.1016/j.jfma.2021.11.011

Coorey, J. (2016). Active learning methods and technology: Strategies for design education. International Journal of Art $\mathcal{E}$ Design Education, 35(3), 337-347. https://doi.org/10.1111/jade.12112

Corral-Lage, J., Iñaki, Peña, J. I. D. L., \& Peña-Miguel, N. (2021). Transformation in economic studies via problem-based learning: facing fears to acquire professional skills. Spanish Journal of Finance and Accounting, 50(3), 359-380. https:// doi.org/10.1080/02102412.2020.1826722

Erikson, M. G., \& Erikson, M. (2019). Learning outcomes and critical thinking-good intentions in conflict. Studies in Higher Education, 44(12), 2293-2303. https:/ / doi.org/10.1080/03075079.2018.1486813

Foo, C.-c., Cheung, B., \& Chu, K.-m. (2021). A comparative study regarding distance learning and the conventional face-to-face approach conducted problem-based learning tutorial during the COVID-19 pandemic. BMC Medical Education, 21(1), 1-6. https://doi.org/10.1186/s12909-021-02575-1

Ganann, R., Ciliska, D., \& Thomas, H. (2010). Expediting systematic reviews: methods and implications of rapid reviews. Implementation Science, 5(1), 1-10. https://doi.org/10.1186/1748-5908-5-56

Garnjost, P., \& Lawter, L. (2019). Undergraduates' satisfaction and perceptions of learning outcomes across teacher-and learner-focused pedagogies. The International Journal 
of Management Education, 267-275. https:// doi.org/10.1016/j.ijme.2019.03.004

Geitz, G., Joosten-ten Brinke, D., \& Kirschner, P. A. (2016). Are marketing students in control in problem-based learning? Cogent Education, 3(1), 1-15. https://doi.org/10.1080/2331186X.2016.1222983

Hajhosseini, M., Zandi, S., Hosseini Shabanan, S., \& Madani, Y. (2016). Critical thinking and social interaction in active learning: A conceptual analysis of class discussion from Iranian students' perspective. Cogent Education, 3(1), 1-9. https://doi.org/10.1080/2331186X.2016.1175051

Hashim, I., \& Samsudin, S. (2020). Practices of problem-based learning (PBL) in teaching Islamic studies in Malaysian public universities. International Journal of Innovation, Creativity and Change, 11(10), 117-129.

Heaviside, H. J., Manley, A. J., \& Hudson, J. (2018). Bridging the gap between education and employment: a case study of problem-based learning implementation in postgraduate sport and exercise psychology. Higher Education Pedagogies, 3(1), 463-477. https://doi.org/10.1080/23752696.2018.1462095

Hidayati, N., Zubaidah, S., Suarsini, E., \& Praherdhiono, H. (2019). Examining the relationship between creativity and critical thinking through integrated problembased learning and digital mind maps. Universal Journal of Education Research, 7(9A), 171-179. https://doi.org/10.13189/ujer.2019.071620

Hidayati, N., Zubaidah, S., Suarsini, E., \& Praherdhiono, H. (2020). The relationship between critical thinking and knowledge acquisition: The role of digital mind maps-PBL strategies. International Journal of Information and Education Technology, 10(2), 140-145.

Hmelo-Silver, C. E. (2004). Problem-based learning: What and how do students learn? Educational Psychology Review, 16(3), 235-266. https://doi.org/10.1023/B:EDPR.0000034022.16470.f3

Hodgkinson, G. P., \& Ford, J. K. (2014). Narrative, meta-analytic, and systematic reviews: What are the differences and why do they matter? Journal of Organizational Behavior, 35(S1), S1-S5. https://doi.org/10.1002/job.1918

Hsu, Y. C. (2021). An action research in critical thinking concept designed curriculum based on collaborative learning for Engineering Ethics course. Sustainability, 13(5), 1-23. https://doi.org/10.3390/su13052621

Hu, W., Jia, X., Plucker, J. A., \& Shan, X. (2016). Effects of a critical thinking skills program on the learning motivation of primary school students. Roeper Review, 38(2), 70-83. https://doi.org/10.1080/02783193.2016.1150374

Ioannou, A., Vasiliou, C., \& Zaphiris, P. (2016). Problem-based learning in multimodal learning environments: Learners' technology adoption experiences. Journal of Educational Computing Research, 54(7), 1022-1040. https://doi.org/10.1177/0735633116636755

Ismail, N. S., Harun, J., Zakaria, M. A. Z. M., \& Salleh, S. M. (2018). The effect of mobile problem-based learning application DicScience PBL on students' critical thinking. Thinking Skills and Creativity, 28(2018), 177-195. https:// doi.org/10.1016/j.tsc.2018.04.002

Jatmiko, B., Prahani, B. K., Munasir, S., Wicaksono, I., Erlina, N., \& Pandiangan, P. (2018). The comparison of OR-IPA teaching model and problem-based learning model effectiveness to improve critical thinking skills of pre-service physics teachers. Journal of Baltic Science Education, 17(2), 300-319.

Kraus, S., Breier, M., \& Dasí-Rodríguez, S. (2020). The art of crafting a systematic literature review in entrepreneurship research. International Entrepreneurship and 
Management Journal, 16(3), 1023-1042. https:/ / doi.org/10.1007/s11365-020-006354

Levac, D., Colquhoun, H., \& O'Brien, K. K. (2010). Scoping studies: advancing the methodology. Implementation Science, 5(1), 1-9. https://doi.org/10.1186/17485908-5-69

Lisniandila, N. P. A., Santyasa, I. W., \& Suswandi, I. (2019). The effect of problem based learning teaching method on students' critical thinking skills in Physics lesson at SMA Negeri 4 Singaraja. JPP (Jurnal Pendidikan dan Pembelajaran), 25(1), 16-24. http:/ /dx.doi.org/10.17977/um047v25i12018p016

Loyens, S. M. M., Jones, S. H., Mikkers, J., \& Gog T. V. (2015). Problem-based learning as a facilitator of conceptual change. Learning and Instruction, 38, 34-42. https://doi.org/10.1016/j.learninstruc.2015.03.002

Md Zabit, M.N., Zachariah, T.Z., Borhan, M. T., Othman, F. \& Ariffin, A.A. (2021). A Proposed Development and Validation of PDPC-PBL Cartoon Concept for Teaching History Module. ICERI2021 Proceedings 14th Annual International Conference of Education, Research and Innovation, 8-9 November.

Meister, J. (2020, 10 April 2020). The impact of the coronavirus on HR and the new normal of work. Forbes Media

LLC. https:/ / www.forbes.com/sites/jeannemeister/2020/03/31/the-impact-of-thecoronavirus-on-hr-and-the-new-normal-of-work/\#178b9d232b60

Moher, D., Shamseer, L., Clarke, M., Ghersi, D., Liberati, A., Petticrew, M., Shekelle, P., \& Stewart, L. A. (2015). Preferred reporting items for systematic review and metaanalysis protocols (PRISMA-P) 2015 statement. Systematic Reviews, 4(1), 1-9. https:/ / doi.org/10.1186/2046-4053-4-1

Moust, J., Bouhuijs, P., \& Schmidt, H. (2019). Introduction to problem-based Learning. Taylor \& Francis.

O'Grady, M. J. (2012). Practical problem-based learning in computing education. ACM Transactions on Computing Education (TOCE), 12(3), 1-16. https://doi.org/10.1145/2275597.2275599

Oderinu, O. H., Adegbulugbe, I. C., Orenuga, O. O., \& Butali, A. (2020). Comparison of students' perception of problem-based learning and traditional teaching method in a Nigerian dental school. European Journal of Dental Education, 24(2), 207-212. https://doi.org/10.1111/eje.12486

Orakci, S. (2021). Exploring the relationships between cognitive flexibility, learner autonomy, and reflective thinking. Thinking Skills and Creativity, 41(9), 1 - 13. https://doi.org/10.1016/j.tsc.2021.100838

Overton, T. L., \& Randles, C. A. (2015). Beyond problem-based learning: using dynamic PBL in chemistry. Chemistry Education Research and Practice, 16(2), 251-259. https://doi.org/10.1039/C4RP00248B

Papp, K. K., Huang, G. C., Clabo, L. M. L., Delva, D., Fischer, M., Konopasek, L., Schwartzstein, R. M., \& Gusic, M. (2014). Milestones of critical thinking: A developmental model for medicine and nursing. Academic Medicine, 89(5), 715-720. https:/ / doi.org/10.1097/ ACM.0000000000000220

Peterson, J., Pearce, P. F., Ferguson, L. A., \& Langford, C. A. (2016). Understanding scoping reviews: Definition, purpose, and process. Journal of the American Association of Nurse Practitioners, 29(1), 12-16. https:/ / doi.org/10.1002/2327-6924.12380

Petrosino, A., Boruch, R. F., Soydan, H., Duggan, L., \& Sanchez-Meca, J. (2001). Meeting the challenges of evidence-based policy: The Campbell Collaboration. The ANNALS of the American Academy of Political and Social Science, 578(1), 14-34. https://doi.org/10.1177/000271620157800102 
Piawa, C. Y. (2010). Building a test to assess creative and critical thinking simultaneously. Procedia-Social and Behavioral Sciences, 2(2), 551-559. https://doi.org/10.1016/j.sbspro.2010.03.062

Ramdan M. R., Abdullah N. L., Mat Isa R. \& Hanafiah M. H. (2021). Organisational ambidexterity within supply chain management: a scoping review. LogForum, 17 (4), 531-546. https://doi.org/10.17270/J.LOG.2021.618

Rumrill, P. D., Fitzgerald, S. M., \& Merchant, W. R. (2010). Using scoping literature reviews as a means of understanding and interpreting existing literature. Work (Reading, Mass.), 35(3), 399-404. https://doi.org/10.3233/wor-2010-0998

Sabah, S., \& Du, X. (2018). University faculty's perceptions and practices of student centered learning in Qatar: Alignment or gap? Journal of Applied Research in Higher Education, 10(4), 514-533. https://doi.org/10.1108/JARHE-11-2017-0144

Saiful, A., Utaya, S., Bachri, S., Sumarmi, S., \& Susilo, S. (2020). Effect of problem based learning on critical thinking skill and environmental attitude. Journal for the Education of Gifted Young Scientists, 8(2), 743-755. https://doi.org/10.17478/jegys.650344

Saputra, M. D., Joyoatmojo, S., Wardani, D. K., \& Sangka, K. B. (2019). Developing criticalthinking skills through the collaboration of jigsaw model with problem-based learning model. International Journal of Instruction, 12(1), 1077-1094.

Saputro, A. D., Atun, S., Wilujeng, I., Ariyanto, A., \& Arifin, S. (2020). Enhancing preservice elementary teachers' self-efficacy and critical thinking using problembased learning. European Journal of Educational Research, 9(2), 765-773.

Sari, Y. I., Sumarmi, Utomo, D. H., \& Astina, I K. (2021). The effect of problem based learning on problem solving and scientific writing skills. International Journal of Instruction, 14(2), 11-26. https:/ / doi.org/10.29333/iji.2021.1422a

Scott, K. S. (2017). An integrative framework for problem-based learning and action learning: Promoting evidence-based design and evaluation in leadership development. Human Resource Development Review, 16(1), 3-34. https://doi.org/10.1177\%2F1534484317693090

Shi, Y., Yang, H., MacLeod, J., Zhang, J., \& Yang, H. H. (2019). College Students' Cognitive Learning Outcomes in Technology-Enabled Active Learning Environments: A Meta-Analysis of the Empirical Literature. Journal of Educational Computing Research, 58(4), 791-817. https://doi.org/10.1177\%2F0735633119881477

Stupnisky, R. H., Renaud, R. D., Daniels, L. M., Haynes, T. L., \& Perry, R. P. (2008). The interrelation of first-year college students' critical thinking disposition, perceived academic control, and academic achievement. Research in Higher Education, 49(6), 513-530. https://doi.org/10.1007/s11162-008-9093-8

Suarniati, N. W., Ardhana, I. W., Hidayah, N., \& Handarini, D. M. (2019). The difference between the effects of problem-based learning strategy and conventional strategy on vocational school students' critical thinking skills in civic education. International Journal of Learning, Teaching and Educational Research, 18(8), 155-167. https:// doi.org/10.26803/ijlter.18.8.10

Suryanti, H. H. S., \& Supeni, S. (2019). A problem based learning (PBL) model in developing students' soft skills aspect. International Journal of Higher Education, 8(8), 62-69. https://doi.org/10.5430/ijhe.v8n8p62

Ulger, K. (2018). The effect of problem-based learning on the creative thinking and critical thinking disposition of students in visual arts education. Interdisciplinary Journal of Problem-Based Learning, 12(1), 1-21. https:/ / doi.org/10.7771/1541-5015.1649

Wale, B. D., \& Bishaw, K. S. (2020). Effects of using inquiry-based learning on EFL students' critical thinking skills. Asian-Pacific Journal of Second and Foreign Language Education, 5(1), 1-14. https://doi.org/10.1186/s40862-020-00090-2 
Wilson, D. M., \& Narasuman, S. (2020). Investigating teachers' implementation and strategies on higher order thinking skills in school based assessment instruments. Asian Journal of University Education (AJUE), 16(1), 70-84. https://doi.org/10.24191/ajue.v16i1.8991

Yağcl, M. (2018). Web-mediated problem-based learning and computer programming: Effects of study approach on academic achievement and attitude. Journal of Educational Computing Research, $56(2)$, 272-292. https:// doi.org/10.1177/0735633117706908

Yew, E. H. J., \& Goh, K. (2016). Problem-based learning: An overview of its process and impact on learning. Health Professions Education, 2(2), 75-79. https:// doi.org/10.1016/j.hpe.2016.01.004

Zmuda, A. (2009). Leap of Faith: Take the Plunge into a 21st-Century Conception of Learning. School Library Monthly, 26(3), 16-18. 